\title{
Using bait lamina and litterbags, two functional methods to monitor biological activity in soil contaminated by dieldrin. Preliminary results from Dakar (Senegal) sahelian region
}

\author{
Ibrahima MBODJ ${ }^{2}$, Makhfousse SARR ${ }^{1}$ and Karamoko DIARRA ${ }^{2^{*}}$ \\ ${ }^{I}$ Ceres/Locustox, $\mathrm{km} 16$ route de Rufisque, BP 3300 Dakar. \\ ${ }^{2}$ Département de Biologie Animale, Faculté des Sciences et Techniques, Université Cheikh Anta Diop de \\ Dakar. \\ *Corresponding author: Email: kdiarra@ucad.sn / karamoko.diarra@ucad.edu.sn \\ Tel: +221774502754
}

\begin{abstract}
The capability of bait lamina to assess biological activity of soil fauna in semi-arid zone was studied in a peri-urban area polluted by dieldrin. This method was compared to litter bags usually used in this savannah region to monitor the activity of soil macro-invertebrates. The study site is used for agriculture and the irrigation water contains known concentrations of dieldrin residues. Three plots were chosen: One plot was soaked with water containing $1.4 \mu \mathrm{g}$ dieldrin/l; another with $1.96 \mu \mathrm{g}$ dieldrin/l and a control without dieldrin. Analysis of dieldrin residue were done from water samples taken from wells used for watering. The feeding activity of soil macro-invertebrates monitored with bait lamina was significantly different between the two contaminated plots and the control, both in absolute numbers and in the vertical distribution. A similar trend had been observed between bait lamina and litter bags despite their differences such as study duration (10 days and 60 days, respectively). Soil dwelling organisms which attack bait lamina were not identified but further study could verify if termites, which are the main soil macro-fauna group in savannah, are responsible for these attacks.

() 2010 International Formulae Group. All rights reserved.
\end{abstract}

Keywords: Bait lamina, dieldrin, sahelian zone, biological activity, litter bags, ecotoxicology.

\section{INTRODUCTION}

In sahelian countries a lot of pesticides are imported to fight the desert locust pest. These agrochemicals cannot entirely be used and then often constitute obsolete stocks. It is the case of dieldrin in many countries plagued by desert locust plagues in the Seventies.

The environmental impact studies of the antiacridian pesticides on terrestrial and aquatic non-target organisms were regularly carried out (Everts and Bâ, 1997; Van der
Valk et al., 2000; Danfa et al., 2002). For the terrestrial ecosystem, soil macro-fauna are the main biological indicators; termites, ants and beetles are the dominant groups in the sahelian terrestrial ecosystem (Sarr, 1999). They play an important role in the dynamics of soil fertility in the savannah (GarnierSillam et al., 1988; Lobry De Bruyn and Conacher, 1990; Black and Okwakol, 1997; Mando and Brussaard, 1999; Dangerfield, 1990; Sarr et al., 2001). For the monitoring of 
these organisms methods such as pitfall traps are used (Van der Valk and Camara, 2002; Danfa et al., 2002) or other methods recommended by the Tropical Soil Biology and Fertility program (Anderson and Ingram, 1993). However, the latter usually disturb the soil structure. In addition, litter bags are used to assess the decomposition of organic matter (Bernhard-Reversat et al., 2000), but this functional method requires a rather long time.

The assessment of the feeding activity with bait lamina was very recently integrated in ecotoxicological studies (Kula and Rombke, 1998; Paulus et al., 1999). This method, developed by Von Törne (1990), has been used in various temperate ecosystems (Kratz, 1998; Larink and Sommer, 2002) and also in tropical rainforests zones (Römbke et al., 2006). With the exception of one study comparing land use types in Benin (Geissen et al., 2001), no work was carried out in the sahelian zone until now.

The objective of this work was to study the potential of the bait lamina method as a quick screening method for the assessment of feeding activity in contaminated soils of the sahelian zone. For this purpose, the results were compared with those obtained from a litterbag study performed at the same site.

\section{MATERIALS AND METHODS}

The study was carried out near a stored dieldrin site located at $14^{\circ} 43^{\prime} 47 \mathrm{~N}^{\prime}, 17^{\circ} 25^{\prime} 49$ $\mathrm{W}$ in a periurban area of Dakar (Senegal). Thousands of litres of dieldrin were stored under non-recommended conditions for several years. In 2002 an important removal campaign of these obsolete stocks was managed by the Senegalese Ministry of Environment and the whole amount of pesticides was removed. A study carried out by TAUW (2002) revealed a contamination of the soil and ground water in nearby inhabited areas and in plots where vegetable are cultivated. The assessment of the biological activity has been carried out in plots located around wells where irrigation water used for vegetable plants had known concentrations of dieldrin. These plots are $10 \mathrm{~m}^{2}$ of surface where vegetables are cultivated. Five litres of water was used daily in plots during 10 days. During experiments, plots had not been disturbed. The plot (P1) was watered with a concentration of dieldrin of $1,4 \mu \mathrm{g} / \mathrm{l}$ and the plot (P2) with a concentration of $1.96 \mu \mathrm{g} / \mathrm{l}$. These concentrations of underground water were analysed in the laboratory of CERES/Locustox with the standards NF EN 12393-2 for pesticides residues in soil and underground water. A control plot was chosen $3 \mathrm{~km}$ upstream of the storage place.

The site of dieldrin storage is located in the isohyets $200-300 \mathrm{~mm}$. The climate is a sahelian type with two distinct seasons: One dry season which extends from November to June with monthly average temperatures between $15{ }^{\circ} \mathrm{C}$ and $20{ }^{\circ} \mathrm{C}$ and a wet season from July to October with monthly average temperatures between $25^{\circ} \mathrm{C}$ and $35^{\circ} \mathrm{C}$. The study area is a part of a landscape of Dakar called "Niayes" which is characterized by a succession of dunes and lowlands.

The tropical ferruginous non-lessivated soil constitutes the main texture on dunes and occupies the major part of the Niayes. These soils are low in organic matter content and often affected by wind erosion and water runoff. In low lands, the mineral soils with pseudo gley are predominant. They are of a great interest in the agricultural production, particularly for vegetable cultivation. The underground water is not deep, quite superficial in some places. The three observed plots are located in lowlands and were chosen around wells where residues of dieldrin had been detected. In plot 2, the farmer applies manure during cycle of cultivation.

The feeding activity of soil fauna was analysed by using bait-lamina obtained from Terra Protecta GMBH (Berlin, Germany). Bait lamina consists of plastic strips 120 $\mathrm{mm} * 6 \mathrm{~mm} * 1 \mathrm{~mm}$, which have a pointed tip at the lower end. In the lower part $(85 \mathrm{~mm})$ of each strip 16 holes of $1.5 \mathrm{~mm}$ diameter are drilled, which are $5 \mathrm{~mm}$ apart from each other. They are filled with bait material. A mixture 
of cellulose $(70 \%)$ and bran $(30 \%)$ powder together with a small amount of activated carbon has been used successfully in many studies performed in temperate regions (Kratz, 1998).

The bait-lamina were established in the two plots soaked with water containing respectively $1.4 \mu \mathrm{g} / \mathrm{l}$ (P 1) and $1.96 \mu \mathrm{g} / \mathrm{l}$ (P 2) of dieldrin residues and in the control plot $(\mathrm{T})$. At each plot, three batches of sixteen baitlamina sticks were used once in the dry season. However this area was regularly soaked because of vegetable cultivation. The 3 batches are aligned at a distance of $2 \mathrm{~m}$ from each other. The bait-lamina was put vertically into the soil, covering a depth from $5 \mathrm{~cm}$ to 15 $\mathrm{cm}$ because of the texture of soil and its dryness. The distance between two neighbouring bait-lamina was $8 \mathrm{~cm}$.

Bait lamina sticks were removed 10 days after setting. Emptied holes were counted for each bait-lamina. For the vertical distribution of the activity, the number of holes perforated per millimetre was also recorded.

The litter bags had a size of 18 to 15 $\mathrm{cm}$ and were made using metal netting. A mesh size of $4 \mathrm{~mm}$ was selected in order to allow access of all soil fauna. For each litter bag, $50 \mathrm{~g}$ of litter were dried at $40{ }^{\circ} \mathrm{C}$ during 24 hours before being introduced into each bag. The litter was taken from small branches of wood (Eucalyptus sp). They were buried in the same plots like the bait lamina but at depth of $10 \mathrm{~cm}$. For each plot 6 litter bags were randomly distributed. All bags were removed 60 days later. Litter was cleaned with a brush and dried as previously described. The percentage of weight lost is determined by the following relation:

$$
\mathrm{X}=\frac{\text { (initial dry weight }- \text { final dry weight) } * 100}{\text { initial dry weight }}
$$

No correction for ash content was made.

\section{Statistical analysis}

The statistical analysis was performed with the software Statview 4.55 (Statview, 1996). The data were subjected to analysis of variance (ANOVA). When differences were detected, Fisher's test $(\mathrm{P}<0.05)$ was applied to separate means.

\section{RESULTS}

Feeding activity as assessed by bait lamina was significantly lower in the plot P2 (watered with a concentration of $1.96 \mu \mathrm{g} / \mathrm{l}$ dieldrin) compared to plot P1 (watered with $1.4 \mu \mathrm{g} / \mathrm{l}$ dieldrin) and the control $\mathrm{T}(\mathrm{F}=16,401$, $\mathrm{p}<0.0001)$. No significant difference was observed between plot $\mathrm{P} 1$ and the control $\mathrm{T}$ (Figure 1).

The vertical distribution of feeding activities shows characteristic differences between the three plots. In plot P 1 the activity is clearly higher in greater depths compared to the top soil layers (nearly 50\% of the biological activity is observed in the horizon 40 to $80 \mathrm{~mm}$ (Figure $2 \mathrm{~A}$ ). In the plot 2, high feeding activity occurs mainly close to the soil surface, i.e. in the first holes located between the 5 to $10 \mathrm{~cm}$ soil layers (Fig. $2 \mathrm{~B}$ ). In control plot $\mathrm{T}$ biological activity was almost homogeneous with a slight decrease in the uppermost $2 \mathrm{~cm}$ of the soil column (Fig. $2 \mathrm{C}$ ). The litter bag study revealed that mass loss was significantly lower in both contaminated plots $\mathrm{P} 1$ and $\mathrm{P} 2$ compared to the control $(\mathrm{F}=$ 20.27, p $<0.0001)$. This weight loss is however not significantly different between plot P 1 and plot P 2 (Figure 3).

\section{DISCUSSION}

This study was focused on the capacity of the bait lamina method to evaluate the biological activity of soils in the sahelian zone. The method was proposed as a quick screening technique to determine the feeding activity of soil invertebrates. Knacker et al. (2003) noted that bait lamina method is reliable, sensitive and reproducible for the assessment of ecological risks (in particular pesticides) in the soil. However, it has not been used for this ecotoxicological purpose in the sahelian zone so far. In fact, rather the litter bags were used to effectively measure the activity of termites which are prevalent in 


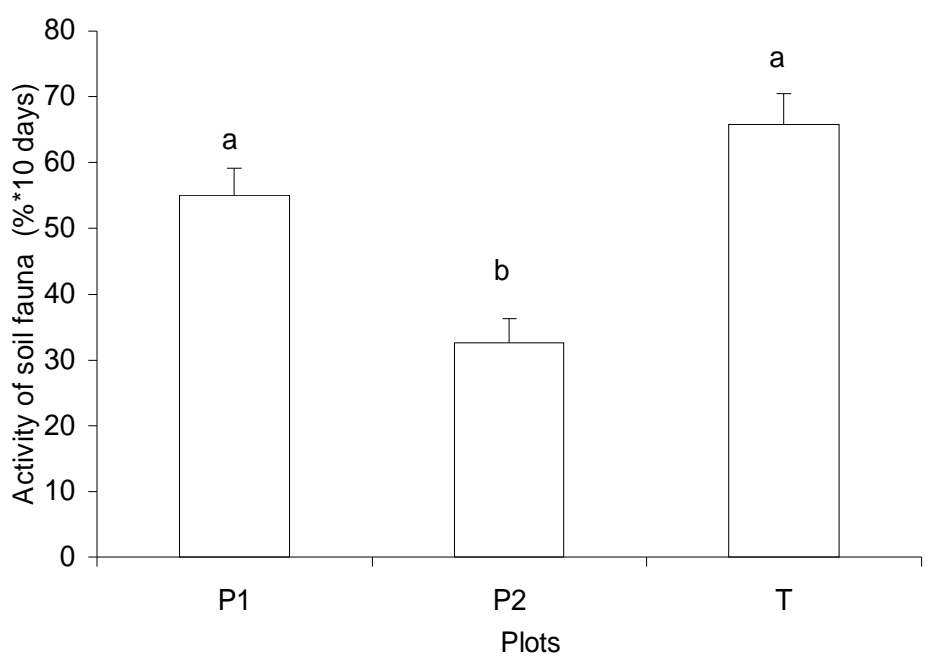

Figure 1: Feeding activity measured by bait lamina in contaminated plots P1, P2 and the control T. Bars with the same letter are not significantly different.

these ecosystems (Lavelle et al., 2001; Ouédraogo et al., 2004).

In this study, both methods were used to assess the impact of dieldrin on the biological (feeding and organic matter decomposition) activity of the soil fauna. With bait lamina, the feeding activity in the plots P1 and $\mathrm{P} 2$ is not different in $20 \mathrm{~cm}$ soil layers. In deeper horizon, feeding activities was considerably reduced in P2. This could be attributed to a longer exposure of soil organisms. The dieldrin may be adsorbed by the soil organic matter and thus allows a longer exposure of the soil organisms. Belfroid et al. (1996) and UNEP and IPCS (1989) reported that the presence of clay particles supports the adsorption and the retention of dieldrin with water. In addition, the vertical distribution showed that feeding activity was high in deeper layers in P1 and control plot. The soil texture of these plots is sandy, so after soaking, the water infiltrated quickly meaning that the exposure of organisms could be reduced in deeper layers.

The litter bag method revealed clear differences between the two contaminated plots and the control. However, while this information was obtained after 60 days the results from the bait lamina method were obtained already 10 days after their installation. These results show the utility of bait lamina in evaluating the feeding activity of the soil rapidly. In addition, these results indicate that the results of bait-lamina studies can be influenced by contaminants but also by soil properties; the difference between P1 and P2 may have been caused by edaphic factors like soil texture. However, the output of these two functional methods is different: with baitlamina the feeding activity and with litter bags the decomposition of organic matter is measured.

In the temperate zone, Van Gestel et al. (2003) and Förster et al. (2004) had noted that the activity of the earthworms is often correlated with bait lamina results. While other authors highlight the role of mesofauna groups (Helling et al., 1998). In the sahelian arid and semi-arid zone, termites represent nearly $60 \%$ of biomass and density of the soil macro-fauna (Sarr et al., 1998; Fall et al., 2000) and they are responsible of the 
A

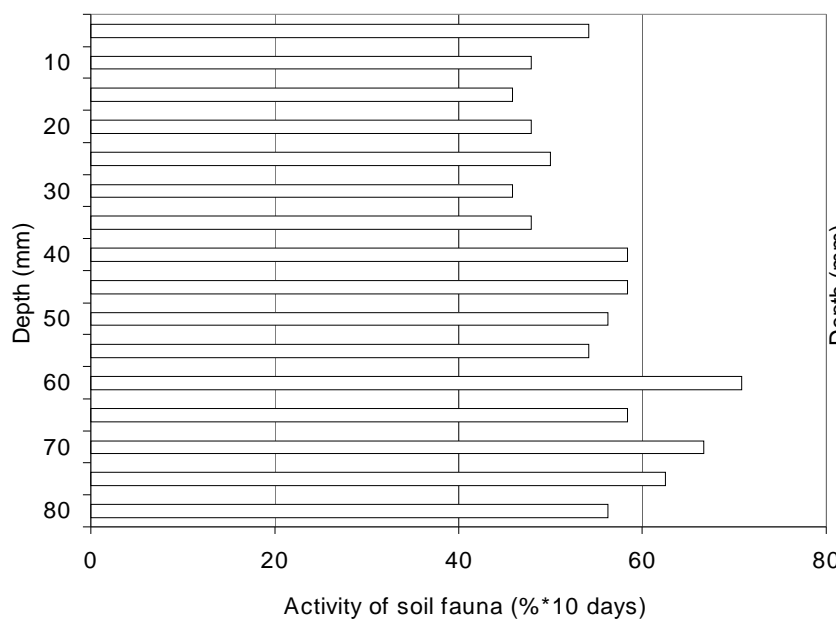

B

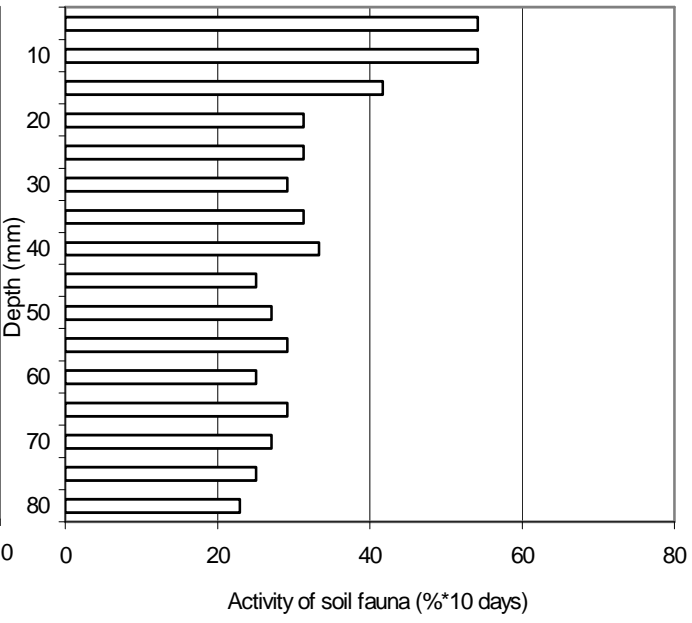

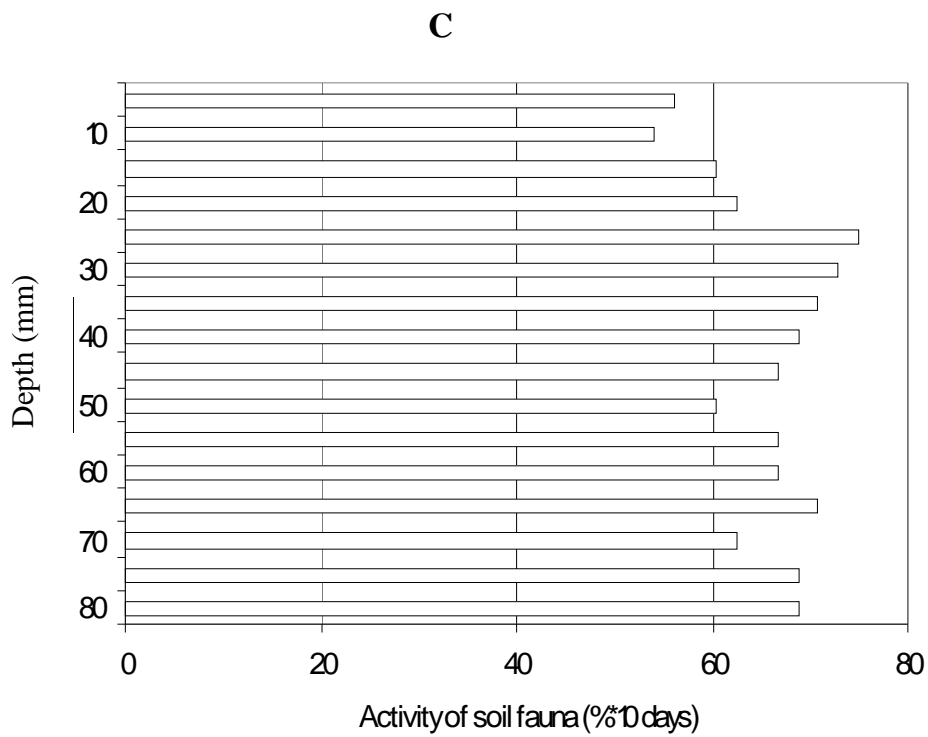

Figure 2: Vertical distribution of feeding activity in plot 1 (A), plot 2 (B) and the control (C). 


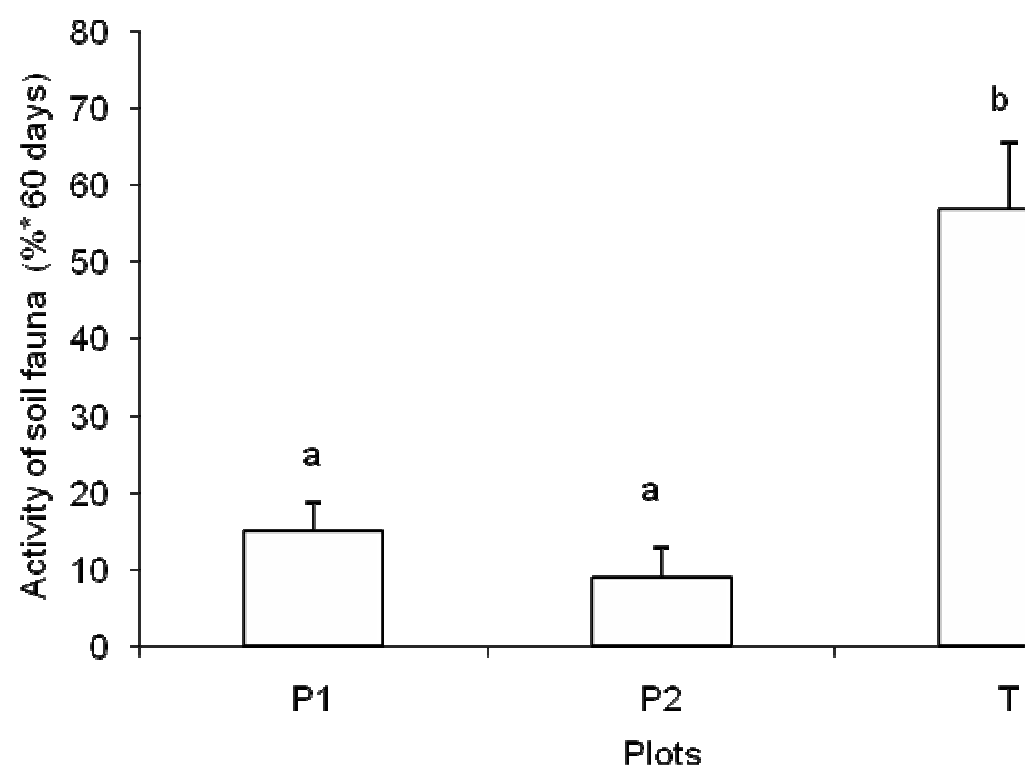

Figure 3: Biological activity measured by litter bags in contaminated plots P1, P2 and the control T. Bars with the same letter are not significantly different.

decomposition of organic matter (Ouédraogo et al., 2004). Their feeding on the bait lamina is probable but cannot be confirmed yet. Other studies would be needed. In addition, the role of microorganisms in the disappearance of the substrate of the lamina baits has to be specified.

\section{Conclusion}

The soil biological activity was evaluated by two functional methods (the baitlamina and litter bags) in two plots which had been irrigated with pesticide-contaminated water. The activity of soil fauna was significantly reduced in both plots of the polluted site for both methods compared with a control plot. The method using the baitlamina for a period of 10 days showed a similar trend compared to that of litter bags buried for 60 days. This rapid method for evaluating the biological activity could be used for future studies.

\section{ACKNOWLEDGMENTS}

The authors are grateful to Dr. Aman Bonaventure Omondi from Kenya, to review the English of this article.

\section{REFERENCES}

Anderson JM, Ingram J. 1993. Tropical Soil Biology and Fertility: A handbook of methods, (2nd edn). C.A.B: Oxford; 221.

Belfroid AC, Sijm DTHM, Van Gestel CAM, 1996. Bioavailability and toxicokinetics of hydrophobic aromatic compounds in benthic and terrestrial invertebrates. Environ. Rev., 4: 276-299.

Bernhard-Reversat F, Masse D, Harmand, JF. 2000. Qualité des litières et décomposition dans les jachères naturelles. In La jachère en Afrique tropicale: Rôles, aménagement, alternatives, Floret Christian, Pontanier Roger (eds). Actes du séminaire international. Paris: John Libbey 
Eurotext, p. 194-203. Séminaire international sur la jachère en Afrique tropicale, 1999-04-13/1999-04-16, Dakar, Sénégal.

Black H, Okwakol MJ. 1997. Agricultural intensification, soil biodiversity and agroecosystem function in the tropics: the role of termites. Applied Soil Ecology., 6: $37-53$.

Danfa A, Ba AM, Van der Valk H, RoulandLefèvre C, Mullié W, Evertsn J. 2002. Long-term effects of chlorpyrifos and fipronil on epigeal beetles and soil arthropods in the semi-arid savanna of northern Senegal. In Environmental Side Effects of Locust and Grasshopper Control. Rapport annuel, Centre for ecotoxicological research in the Sahel, 4: $184-213$.

Dangerfield JM. 1990. Abundance, biomasse and diversity of macro-fauna in savana woodland and associated managed habitats. Pedobiologia., 34: 141-150.

Everts J, Bâ L. 1997. Les effets environnementaux de la lutte chimique contre les acridiens. In Effets de la Lutte Antiacridienne sur l'Environnement: Rapport annuel Centre for ecotoxicological research in the Sahel, 1 : $1-17$.

Fall S, Sarr M, Rouland C, Agbogba C, Brauman A. 2000. Influence de l'âge de la jachère et de la saison sur la densité et la biodiversité des termites. Cas des jachères de Saré Yorobana (Haute Casamance, Sénégal). In La Jachère en Afrique Tropicale, Rôles, Aménagement, Alternatives. Actes du séminaire international. Paris : John Libbey Eurotext, 1: 294-302.

Förster B, Vangestel C, Koolhaas JE, Nentwig G, Rodrigues. 2004. A Terrestrial Model Ecosystem (TME), an instrument for testing potentially harmful substances: effects of carbendazim on organic matter breackdown and soil fauna feeding activity. Ecotoxicology., 13: 129 - 141.
Garnier-Sillam TF, Renoux J. 1988. Comparaison de l'influence de deux termitières (humivore et champignonnistes) sur la stabilité structurale des sols tropicaux forestiers. Pedobiologia., 32 : 89-97.

Geissen V, Junge B, Skowronek A. 2001. Einfluss unterschiedlicher Nutzung auf bodenökologische Kennwerte tropischer Böden der Feuchtsavanne Benins. Mitteilungen der Deutschen Bodenkundlichen Gesellschaft, 96(1): 329-330.

Helling B, Pfeiff G, Larink O. 1998. A comparison of feeding activity of collembolan and enchytraeid in laboratory studies using the bait-lamina test. Applied Soil Ecology., 7: 202 - 212.

Knacker T, Förster B, Römbke J, Frampton GK. 2003. Assessing the effects of plant protection products on organic matter breakdown in arable fields-litter decomposition test systems. Soil Biology and Biochemistry., 35: 1269 - 1287.

Kratz W. 1998. The bait-lamina test: General Aspects, Applications and Perspectives. ESPR - Environ. Sci. Pollut. Res., 5(2): 94-96.

Kula C, Rombke J. 1998. Evaluation of soil ecotoxicity tests with functional endpoints for the risk assessment of plant protection products - State of the art. Environmental Science and Pollution Research., 5: 55-60.

Larink O, Sommer R. 2002. Influence of coated seeds on soil organisms tested with bait-lamina. European Journal of Soil Biology., 38: 287-290.

Lavelle P, Barros E, Blanchart E, Brown G, Desjardins T, Mariani L, Rossi JP. 2001. SOM management in the tropics: Why feeding the soil macro-fauna? Nutrient Cycling in Agroecosystems., 61: 53-61.

Lobry De Bruyn, Conacher AJ., 1990. The role of termites and ants in soil modification: a review. Australian Journal of soil Research., 28: 55 - 93. 
Mando A, Brussaard L. 1999. Contribution of termite to the breakdown of straw under sahelian condition. Biol. Ferti. Soil., 29: 332-334.

Ouédraogo E, Mando A, Brussaard L. 2004. Soil macro-faunal - mediated organic resource disappearance in semi-arid West Africa. Applied Soil Ecology., 27: 259 267.

Paulus R, Röembke J, Ruf A, Beck L. 1999. A comparison of the litterbag-, minicontainer- and bait-lamina- methods in an ecotoxicological field experiment with diflubenzuron and btk. Pedobiologia., 43: 120 - 133.

Römbke J, Höfer H, Garcia MVB, Martius C. 2006. Feeding activities of soil organisms at four different forest sites in Amazonia using the bait lamina method. J. Trop. Ecology., 22: 313-320.

Sarr M, Agbogba C, Russell-Smith A. 1998. The effect of lenghts of fallow and cultivation on termite abundance and diversity in the sahelian zone of Senegal: A preliminary note, Pedobiologia., 42: 56-62.

Sarr M. 1999. Etude écologique des peuplements de termites dans les jachères et dans les cultures en zone soudanosahélienne, au Sénégal. Thèse de $3^{\mathrm{è}}$ cycle, Université Cheikh Anta Diop de Dakar, Dakar, p. 117.

Sarr M, Russell-Smith A, Agbogba C, Masse D. 2001. The effects of soil faunal activity and woody shrubs on water infiltration rates in fallows in the sahelian zone of Senegal. Applied Soil Ecology., 16(3): $283-290$.
Statview. 1996. Abacus Concepts, Version 4.55, 1918 Bonita Avenue, Berkeley, CA 94704-1014 (USA).

TAUW 2002. Site Investigation and Risk Assessment at Rufisque (Dakar, Senegal). Final report. 28p.

UNEP, IPCS. 1989. Aldrin and dieldrin: Environnemental health criteria; 91. Geneva (World Health Organization). Published under the joint sponsorship of the United Nations Environment Programme, the International Labour Organization, and the World Health Organization. 335 p.

Van der Valk H, Camara O. 2002. Side effect of chlorpyrifos and deltamethrin in a sahelian millet agrosystem, 1997. In Environmental Side Effects of Locust and Grasshopper Control. Centre for Ecotoxicological Research in the Sahel, 4: $150-183$.

Van der Valk H, Niassy A, Danfa A. 2000. The impact of locust control insecticides on termites and ants in the arid zone of northern Senegal: a first assessment 1999. In Environmental Side Effects of Locust and Grasshopper Control. Centre for Ecotoxicological Research in the Sahel 4: $110-132$.

Van Gestel CAM, Kruidenier M, Berg MP. 2003. Suitability of wheat straw decomposition, cotton strip degradation and bait-lamina feeding tests to determine soil invertebrate activity. Biol. Fertil. Soil., 37: 115-123.

Von Törne EV. 1990. Assessing feeding activities of soil-living animals. I. Baitlamina-tests. Pedobiologia., 34: 89 - 101. 